А. А. Новикова

Орел

DOI: 10.15393/j9.art.2011.308

\section{ХУДОЖЕСТВЕННОЕ БОГОПОЗНАНИЕ В ТВОРЧЕСТВЕ Н. С. ЛЕСКОВА}

Г лубоко занимавшая Лескова проблема боговедения, богопознания соотносится с особой природой его художественного творчества. Писатель, испытывая, по его словам, "томления духа", "духовной жаждою толил", искал способы утолить эту «жажду». В своем творчестве он представил художественный взгляд на "лир Божий, который превыще всякого улал (Флп. 4:7).

Согласно собственному признанию, Лесков имел «счастливую религиозность», позволявшую "лирить веру с рассудкол $»^{1}$. Вера - это не вопрос интеллекта. Православное апофратическое познание отказывается от попыток исчерпать глубины веры логическим путем: душа знает то, чего не знает разум. Православие включает в свое учение мистику как «область, не доступную познанию, как неизреченную тайну, сокровенную глубину» ${ }^{2}$. В исключительно богатой восточной агиографии неоднократно описан опыт внерационального постижения Бога, очень волновавший Лескова. Е. Борхсениус, близко знавшая писателя в последние годы его жизни, утверждала, что он «любил кра-

(C) Новикова А. А., 2011

1 Лесков Н. С. Собр. соч.: В 11 т. М.: ГИХЛ, 1956-1958. Т. 11. С. 11. Далее ссылки на это издание приводятся в тексте с обозначением тома римской и странищ - арабскими цифрами.

2 Лосский В. Н. Очерк мистического богословия восточной Церкви. Догматическое богословие. М.: Центр «СЭИ», 1991. С. 8. соту православного богослужения и в глубине души оставался мистиком» ${ }^{3}$. «Мистически несвободным» называл отца Андрей Лесков. «Делалось страшно за несовершенство нашего ума, за неточность и бессилие человеческого слова выразить то, что хочет открыть вездесущий и все наполняющий Дух» ${ }^{4}$ - таковы писательские и религиозные «томления» Николая Семеновича Лескова. При всем этом он обладал удивительным дарованием запечатлеть в слове мистический опыт христианской веры, ярко передать ее эмоџиональную и духовную природу, экстатические стороны и сакральные глубины, религиозное состояние духа, не рационализируемое в принципе.

Писатель открыл для себя «любопытное и прекрасное Богопознание» у знаменитого баснописца И. А. Крылова:

По непонятной странности, у нас есть довольно много людей, которые знают наизусть большую оду Державина о Боге, а никто никогда не приводит, какое представление о Боге имел Крылов. А оно очень кратко и прекрасно. Крылов говорит: Чтоб Бога знать, быть надо Богом, Но чтоб любить и чтить Его,

Довольно сердца одного ${ }^{5}$.

В православной антропологии сердце - тот центр, куда должна быть сведена вся работа по самособиранию человека. Лесков продолжает:

Определение это мне кажется прекрасным, и таким же оно казалось архиереям, которым я говорил о нем, и просвещенному буддисту из японского посольства, который записал себе это крыловское Богопознание и сказал: «Это может объединить все понятия» ${ }^{6}$.

Ярким выражением художественного богопознания Лескова явилась повесть «На краю света» (1876), впервые опубликованная в святочных номерах журнала «Гражданин» с подзаголовком "рождественский рассказ". Концепция

${ }^{3}$ Борхсениус Е. И. Мои воспоминания о Николае Семеновиче Лескове // В мире Лескова. М.: Сов. писатель, 1983. С. 343.

4 Лесков Н. С. Новозаветные евреи (рассказы кстати) // Новь. 1884. T. 12. C. 76 .

${ }^{5}$ Он же. Боговедение баснописца (Post-scriptum об Иване Андреевиче Крылове) // В мире Лескова. М.: Сов. писатель, 1983. С. 364-365. ${ }_{6}^{6}$ Там же. 
«На краю света» - «спасительного урока в одном чудесном событии» ${ }^{7}$ - рождественская в ее кульминационных точках чуда, спасения, дара.

Главное в повести не только «открытие человека», но и открытие Бога, богоискание и богопознание, пребывание в Боге. Признавая вослед за Тертуллианом, что «душа по природе христианка» (XI, 456), Лесков показывает возможность прямого, без посредников, обращения к Богу, непосредственного Богообщения, тем самым утверждая ценность и достоинство человеческой личности. Это христианская концепция синергизла - сотрудничества Божественного и человеческого, благодати Творца и свободного усилия твари. Вот почему изданию дилогии «На краю света» и «Владычный суд» (с подзаголовком «Pendant к pacсказу "На краю света"») писатель дал глубоко православное название «Русские богоносцы» $(1880)^{8}$. Христианская «неисчерпаемость» повести ведет к особенному роду мировидения и творческого созидания. Сближая веру с личным эстетическим переживанием, Лесков рассчитывает на созвучное индивидуально душевное состояние воспринимающих его произведение.

Писатель сумел подметить различные особенности в восприятии Христа - в простом народе и в светском салоне, в монашеской келье и среди некрещеных «дикарей»:

...вот вам сколько пониманий и представлений о Том, Кто один всем нам на потребу! $(1,338)$.

Но главное для Лескова то, что к богопознанию призван любой человек, созданный «по образу и подобию» Божию.

Одна из центральных идей повести - о «русском Христе» «за пазушкой» $(1,348)$. Писатель исповедует именно такое "христопонимание», освещающее своим благодатным светом русскую жизнь и все бытие человеческое:

...я более всяких представлений о божестве люблю этого нашего русского Бога, который творит себе обитель «за пазуш-

${ }^{7}$ Лесков Н. С. Собр. соч.: В 12 т. М.: Правда, 1989. Т. 1. С. 339. Далее ссылки на это издание приводятся в тексте с обозначением тома и страницы арабскими цифрами.

${ }^{8}$ Лесков Н. С. Русские богоносцы. СПб., 1880. кой». Тут, что нам господа греки ни толкуй и как ни доказывай, что мы им обязаны тем, что и Бога через них знаем, а не они нам Его открыли; не в их пышном византийстве мы обрели Его в дыме каждений, а Он у нас Свой, притоманный, и по-нашему, попросту, всюду ходит $(1,348)$.

Лесковское описание лика Христа в изображении «наших старых мастеров»: «...взгляд прям и прост... в лике есть выражение, но нет страстей... черты чуть слегка означены, а впечатление полно» $(1,338)$ духовно и эстетически соотносит «На краю света» с иконописью повести «Запечатленный Ангел» (1873), получившей тот же авторский жанровый подзаголовок "рождественский рассказ". Писатель особо отметил «рабский вид» Царя Небесного - как «наше народное искусство поняло внешние черты Христова изображения, и народный дух наш, может быть, ближе к истине постиг и внутренние черты Его характера» (1, 339). Значимо в этой связи, что первому отдельному изданию «На краю света» (1876) Лесков предпослал эпиграфр из стихотворения Тютчева «Эти бедные селенья...»:

$$
\begin{aligned}
& \text { Удрученный ношей крестной, } \\
& \text { Всю тебя, земля родная, } \\
& \text { В рабском виде Царь Небесный } \\
& \text { Исходил, благословляя }
\end{aligned}
$$

Поэтические строки созвучны лесковскому описанию русского изображения Христа:

Мужиковат Он... и в зимний сад Его не позовут послушать канареек, да что беды! - где Он каким открылся, там таким и ходит, не имея где главы приклонить от Петербурга до Камчатки $(1,339)$.

Так, уже в фринале экспозиции перебрасывается «мостик» к основному действию повести, которое происходит на «краю света», в северной пустыне на «краю земли». И вместе с тем отчетливо обозначается ведущая идея повествования - мысль о Христовом всеприсутствии, всепроникновении, что становится исповеданием Бога и для

\footnotetext{
9 «Христос народного сознания, - писал Ю. Селезнев, — тот народный идеал, что в "рабском виде... исходил, благословляя" русскую землю" (Селезнев Ю. Лесков и Достоевский // В мире Лескова. М.: Сов. писатель, 1983. С. 141).
} 
главных героев, и для «слушателей» архиерейского рассказа, и для самого автора.

Владыка, согласно его же самохарактеристике, человек нетерпеливый и раздражительный, по прибытии в отдаленную сибирскую епархию решает «всего себя посвятить трудам по просвещению диких овец» своей паствы $(1,343)$. Епископу представляется, что «заблудшие овщы», не ведающие о Христе, и живут без Христа. Этому мнению противостоит иное суждение: «монашек» «бедного монастырька» $(1,343)$. Кириак уверен, что Христос «и шелудивой овцой не брезговал, а где найдет ее, взвалит Себе, как она есть, на святые рамена и тащит к Отцу» $(1,357)$. Истина открывается в богословских прениях владыки с его оппонентом.

Формализованное крещение (по лесковскому слову "примазывание»10) герой повести праведный отец Кириак почитает за «великий грех»: 350)

...во Христа-то крестимся, да во Христа не облекаемся! (1,

Не следует «ловким крестителям» поставлять «внешних христиан» $(1,360)$ :

...нечего спешить нарекать, а надо насаждать; другие придут - будут поливать, а возрастит сам Бог $(1,363)$.

Таков основной смысл религиозной педагогики Лескова, ратующего за то, чтобы вера была не только «нареченной», но действенной.

Сам владыка сталкивается с реальной сложностью задачи крещения «диких»:

...рожа обмылком - ничего не выражает; в гляделках, которые стыд глазами назвать, - ни в одном ни искры душевного света; самые звуки слов, выходящих из его гортани, какие-то мертвые: в горе ли, в радости все одно произношение, вялое и бесстрастное... Где ему с этими средствами искать отвлеченных истин и что ему в них? $(1,370)$

${ }^{10}$ Лесков Н. С. Иродова работа (Русские картины в Остзейском крае) // Исторический вестник. 1882. T. VIII. Апрель. С. 191. Писатель показал, что во многих случаях крещение исполнялось как пустая формальность, однако же это было провозглашено в печати как «триумф мальность, однако же это было провозглашено в печати как «триумфо
православия». См.: Лесков Н. С. Торжество православия // Петербургская газета. 1881. № 90 .
Однако же талантливые святители и в такой ситуации находили возможность донести слово Божие. Так, когда епископ Иннокентий занялся переводом молитвы "Oтче наш" для алеутов, то столкнулся с проблемой:

...алеуты не знали, что такое хлеб, им надо было объяснять это. А хлебом у них была «рыба», и тогда святитель слово "хлеб» в фрразе "хлеб наш насущный» перевел словом «рыба», и молитва была услышана. Это как раз пример того, что молитвой передается дух, а не буква ${ }^{11}$.

Крещение «скорохватом» $(1,353)$ предполагает, будто «дикари вовсе лишены Сына Божия, и этим как бы удостоверяет отсутствие Сына Божия из части творения; на самом же деле - Он в них присутствует, хотя они и не научены еще исповеданию этого присутствия» ${ }^{12}$.

Отвечая на суровые возражения миссионера-архиерея, «монашек» пересказывает ему легенду древнего патери ка о христианине и язычнике, который также был принят Христом, «потому что когда язычнику никто не докучал настойчивостью, он сал с собою размышлял о Христе и призвал Его в своем последнем вздохе» $(1,354)$. «Предания человеческие» подкрепляются авторитетом «слова Божия»:

...вспомни, разве не писано: будут и крещеные, которые услышат «не вем вас», и некрещеные, которые от дел совести оправдятся и внидут, яко хранившие правду и истину $(1,350)$.

Отец Кириак напоминает здесь о словах Евангелия:

Не всякий, говорящий Мне: «Господи! Господи!» - войдет в Царство Небесное, но исполняющий волю Отца Моего Небесного (Мдp. 7:21).

И тогда объявлю им: «Я никогда не знал вас; отойдите от меня, делающие беззаконие» (Мфр. 7:23).

Реченное воплощается в повести почти буквально: крещеный проводник обрекает на гибель старца Кириака, а некрещеный совершает дело Божеское: рискуя собственной жизнью, спасает архиерея, погибающего в снежной пустыне.

${ }^{11}$ Иоанн, архиепископ Белгородский и Старооскольский. Дар молитвы // Крест. 2001. № 2. С. 10.

${ }^{12}$ Дурылин С. Н. О религиозном творчестве Н. С. Лескова // Христианская мысль. 1916. № XI. С. 79 . 
Религиозная мораль отца Кириака попала в столкновение с «политикою» современной «многодумной и дурашливой поры» $(1,358)$ :

...как придут новокрещенцы в город и видят все, что тут крещеные делают, и спрашивают: можно ли то во славу Христову делать? что им отвечать, владыко? Христиане это тут живут или нехристи? Сказать: «нехристи» - стыдно, назвать христианами - греха страшно $(1,355)$.

Упование героя связано с жаждой Христова света в превосхождении этого «каверзливого времени» $(1,358)$ ради «жизни будущего века». Вот как Лесков оценивает своего праведного героя:

Он был своего рода новатор, и, видя этот обветшавший мир, стыдился его и чаял нового, полного духа и истины $(1,356)$.

Последняя молитва праведника, отдающего свой дух Богу, «за всех». С этим словом «он - точно поволокся за Христовою ризою, - и улетел» $(1,391)$.

Писатель не раз размышлял о том, кто достоин Царствия Небесного. В «рождественском рассказе» «На краю света» впервые появляется образ-символ «билета», развитый затем в «Братьях Карамазовых» (1881) Достоевским. Лесков пишет:

Ну а теперь мы видим, что рядом с нами туда же бредет человечек без билета. Мы думаем: «Вот дурачок! Напрасно он идет: не пустят его! Придет, а его привратники вон выгонят». А придем и увидим: привратники-то его погонят, что билета нет, а Хозяин увидит, да, может быть, и пустить велит, скажет: «Ничего, что билета нет, - Я его и так знаю: пожалуй, входи», - да и введет, да еще, гляди, лучше иного, который с билетом пришел, станет чествовать $(1,355)$.

Таким образом, доброму язычнику не закрыт путь в Царствие Небесное, ибо всякое добро и благо восходят ко Хриcmy. Некрещеные «дикари» и «сами не чуют, как края ризы Его касаются. <...> Пусть за краек Его ризочки держатся доброту Его чувствуют, а Он их Сам к Себе уволочет» (1, 357).

Основное отличие русской святочной литературы от западноевропейской традиции - воплощение не столько «карнавального начала», культуры «смеховой»13, сколько культуры «световой». Это свет Вифлеемской звезды, просиявшей на востоке в момент рождения Младенца Иисуса; тот самый «Свете тихий» русской молитвы - предсказания о пришествии Сына Божия в мир, "нетленный Свет», «Свет присносущный», о котором совершается моление в дни Рождества:

Возсияй в сердцах наших, Человеколюбче Владыко, Твоего богоразумия нетленный Свет, и мысленая наша отверзи очи, во евангельских Твоих проповедуй разумение.

Бог есть свет (1 Ин. 1:5).

Свет истинный, Который просвещает всякого человека (Ин. 1:9).

Евангельский контекст позволяет истолковать заглавие "рождественского рассказа" Лескова в метафризическом смысле: "На краю света», то есть «на краю светоносной ризы Христовой, за которую весь мир (весь свет) держится. Об этом «краешке ризы», за которую держатся все без исключения Божьи создания, только иногда сами не заме чают, как «крайка коснулись» $(1,369)$, не устает повторять «человек преутешительный» $(1,21)$ отец Кириак. Он молится о том, чтобы «слепые» стали «зрячими», то есть «просветились», увидели свет Христов:

Да просветится свет Твой пред человеки, когда увидят добрыя Твоя дела $(1,352)$

«Люблю эту русскую молитву» $(1,391)$, - признается герой-рассказчик, и это люблю - из уст самого Лескова, повесть которого пронизана религиозным лиризмом. Писатель так же жаждал внутреннего просветления людей, чтобы те смогли очистившимися душами узреть Божественный свет.

К подобному «христопониманию» постепенно подходит и герой-рассказчик архиерей, «собирая в уме своем» разные молитвенные обращения к Богу, пока они не вылились в итоге повести в слова чудесной молитвы «за всех», за весь мир, держащийся за «край света», за край «ризы

${ }^{13}$ См.: Бахтин М. М. Творчество Франсуа Рабле и народная культура Средневековья и Ренессанса. М.: Худож. лит., 1965. 
Христовой». «Рождественский рассказ» «На краю света» весь одухотворен молитвенным пафосом, весь целиком напоминает молитву, которая в финнале повествования увенчалась единодушным («едиными усты и единым сердцем») возгласом: "Аминь!» $(1,396)$. «На краю света» - как художественное молитвословие - все пронизано светом, светоносно. У Лескова это знак перехода от текста в сфреры внетекстовые.

Писатель выстраивает некоторые эпизоды повести, обращаясь непосредственно к Библии, соединяя несколько цитат в связный текст, представляющий собой как бы «комбинированную цитату» из библейских изречений Книги Иова $^{14}$; опирается также на молитвословия высокочтимого им древнерусского святого подвижника Кирилла Туровского $^{15}$. Эти художественные приемы красноречиво свидетельствуют о том, что Лесков, будучи человеком православной культуры, сохранял в своей памяти множество библейских и литургических текстов — то, что епископ Игнатий (Брянчанинов) называл подвигом «стяжания Евангелия памятью» ${ }^{16}$. Благодаря своей органичной религиозности писатель приобрел неповторимый художественный стиль и смог воссоздать тот христианский идеал, к которому стремился.

Мотивы лесковского «рождественского рассказа» «На краю света" отчетливо различимы в "святочном рассказе» В. Г. Короленко "Сон Макара» $(1883)^{17}$. Лесков рано разглядел дарование Короленко, называя его имя в числе талантливых молодых писателей (см.: XI, 139), а в некото-

${ }^{14}$ См.: Ильяшенко T. А. Библейские и богослужебные элементы в прозе Н. С. Лескова: Авторефр. дис. ... канд. филол. наук. М., 2002. С. 10-11.

${ }^{15}$ См.: Столярова И. В. Молитва Кирилла Туровского в художественной системе рассказа Н. С. Лескова "На краю света» // Евангельский текст в русской литературе XVIII-XX веков. Цитата, реминисценция, мотив, сюжет, жанр. Вып. 4. Петрозаводск: Изд-во ПетрГУ, 2005. С. 365380 .

${ }^{16}$ Игнатий (Брянчанинов), епископ. О чтении Евангелия // Игнатий (Брянчанинов), епископ. Сочинения. Т. 1. СПб., 1905. С. 110.

${ }^{17}$ См. об этом в моей монографии: Кретова А. А. (Новикова А. А.) «Будьте совершенны»: Религиозно-нравственные искания в святочном творчестве Н. С. Лескова и его современников. М.; Орел, 1999. С. 180203. рых вопросах фолософии веры и познания о Боге маститый писатель в чем-то даже совпадал с молодым автором: «Мне очень понравилась франтазия Короленки "Тени”, писал Лесков Чертковой в 1894 году. —Я тоже так думаю, что определенного познания о Боге мы получить не можем при здешних условиях жизни, да и вдалеке это еще не скоро откроется, и на это нечего досадовать, так как в этом, конечно, есть воля Бога» (XI, 577).

Идея о непознаваемости Бога человеческим разумом («инструмент наш плох и не берет этого» $(5,96)$, - утверждал писатель в романе «На ножах" - 1871) сочетается у Лескова с богопознанием путем интуитивного открытия человеком Божественной премудрости: «Куда ни глянь все чудо: вода ходит в облаке, воздух землю держит, как перышко; вот мы с тобою - прах и пепел, а движемся и мыслим, и то мне чудесно; а умрем, и прах рассыплется, а дух пойдет к Тому, Кто его в нас заключил. И то мне чудно: как он наг безо всего пойдет? Кто ему крыла даст, яко голубице, да полетит и почиет?» $(1,347)$ - радостно удивляется «дивотворному» благоустроению мира отец Кириак.

В финале повести, используя прием композиционного кольца, Лесков снова поднимает вопрос об антитетичности «салонной христовщины» иностранных проповедников, заезжих «чудодеев», которые «бряцают, как кимвал звенящий, в ваших гостиных и ваших зимних садах» (1, 395), и истинно народного знания о Боге: «...где в дебрь из дебри ходит наш Христос - благий и добрый и, главное, до того терпеливый» $(1,395)$, что не под силу представить «великосветским религиозным нетерпеливцам» $(1,393)$.

Будучи связанным с православной традицией с детства, до последних лет жизни сохранял писатель глубокие чувства к литургии и музыке Русской православной церкви. Любимейший Лесковым великий канон Андрея Критского «Помощник и покровитель бысть мне во спасение...» и другие церковные песнопения вызывали духовный и эстетический восторг писателя:

Какие мастера! Сколько вдохновения... Сколько вкуса, величественной простоты! Куда до них этим куцым латинянам с их реверансами перед алтарями, звоночками и кастратами. 
Непревзойденные художники и древние неведомые композиторы, и наши Бортнянский, Турчанинов... Великие мастера! ${ }^{18}$

Лескова завораживала красота русских икон ${ }^{19}$ :

...в священной русской иконописи изображается тип лица небожительный, насчет коего материальный человек даже истового воображения иметь не может $(1,423)$.

Иконописное искусство как источник особой эстетики сопрягалось с литературной образностью, служило развитию и усилению самобытного типа художественности. Уникальное в истории литературы творение художника «Запечатленный Ангел» (1873), в котором икона стала главным «действующим лицом».

В лесковском «иконописном» фррагменте сохраняется стиль русской агиографии во всей его чистоте и красоте, как он представлен у лучших писателей Древней Руси Нестора, Епифрания Премудрого, Пахомия Логофрета. Богатство словесной культуры, развитая риторика, пышно изукрашенное «плетение словес» и - главное - нравст-

${ }^{18}$ Цит. по: Лесков А. Н. Жизнь Николая Лескова: По его личным, семейным и несемейным записям и памятям: В 2 т. М.: Худож. лит., 1984. T. 2. С. 316 .

${ }^{19} \mathrm{C}$ годами писатель приобрел репутацию одного из лучших знатоков русской иконы. В кабинете Лескова имелось иконописное собрание, судьба которого сейчас неизвестна. Однако сохранился рисунок с иконостатической коллекции Лескова, и мы знаем, как выглядела божничка писателя. Все иконы на рисунке различимы, узнаваемы. В. В. Протопопов вспоминал огромный образ Мадонны кисти Боровиковского «русский лик и отчасти как бы украинский». У Лескова были редкие поморские складни, старинные иконы строгановского и заонежского письма. Возможно, что в «Запечатленном Ангеле» Лесков дает точное описание подлинника: "Ангел-хранитель, Строганова дела» $(1,400)$. В Доме-музее Н. С. Лескова в Орле хранятся три иконы. Одна из них «Спас во звездах» - с дарственной надписью: эту икону писатель преподнес сыну в конце Святок 1891 года и благословил на брак, что полностью отвечает этикету православного благочестия.

О глубоком увлечении писателя иконописью см. также: Макарова E. A. Русская икона в эстетическом восприятии Н. С. Лескова // Культура Отечества: прошлое, настоящее, будущее. Вып. 2. Томск, 1994. C. 79-83; Колова M. А. «Запечатленные Ангелы» Никиты Рачейскова и образ Спаса из иконописного собрания Н. С. Лескова // Патристическое наследие: Традиции религиозно-философской и педагогической мысли в России. Орел: ОГУ, 2002. С. 270-281. венная серьезность перед лицом красоты. Художественное молитвословие представлено как воспитание личности, как постижение мира через Божественную гармонию. Сложные, многокорневые слова, усвоенные православной гимнографией из традиции торжественной церковной риторики, выражают благоговение перед святыней, и в какой-то мере чувство бессилия достойно на человеческом языке воспроизвести святой образ:

Лик у него... самый светлобожественный и этакий скоропомощный $(1,400)$.

По справедливой мысли С. С. Аверинцева, старинное слово "благообразие» выражает «идею красоты как святости и святости как красоты. Красота тесно связана в русской народной психологии с трудным усилием самоотречения» ${ }^{20}$.

В «рассказе кстати» «Таинственные предвестия» (1885), в котором Лесков в очередной раз проявил себя как глубокий знаток церковной истории, писатель показал православную литургию под открытым небом в волнующем эпизоде богослужения на пароходе, плывущем к Валааму Оказавшиеся на этом «подвижном монастыре» $(7,388)$ священнослужители - именно такие, в каких, по Лескову, нуждается Церковь, - владыка Никанор, «знаменитый синолог, архимандрит Аввакум, известный по своей учености, по благородной прямоте характера, по неукротимой пылкости» (7, 381), архимандрит Игнатий Брянчанинов (герой лесковского рассказа о «праведниках» «Инженерыбессребреники»), который «знал и светское, и духовное.. обладал еще ласкою и уветливостью прекрасного характера» (7, 385), протодиакон-монах Виктор - «тихий, смирный, голосистый», с замечательной манерой «вести служение в величайшей тишине и стройности» $(7,385)$ - отслужили всенощную, благословив «царство вездесущего Бога под открытым куполом Его нерукотворного храма» $(7,389)$.

Лесков-художник воссоздает созидательные по своей природе благодатные религиозные чувства «живого восторга»:

${ }^{20}$ Аверинщев С. С. Крещение Руси и путь русской культуры // Контекст. М.: Наука, 1990. С. 70. См. также: Трубецкой E. Три очерка о русской иконе. Новосибирск: Сибирь. XXI век, 1991. 
...кто попал на эту отпетую без книг вечерню, стали на колена, - некоторые плакали... О чем и для чего? - ведает Тот, Кому угодно было, чтобы «благоухала әфирною душою роза» и чтобы душа находила порою отраду и счастье омыться слезою $(7,389)$.

Художественный эффрект тщательно готовится всем строем повествования. Фигура умолчания деликатно указывает на словесно не выразимые благодатные чувства молящихся.

«Рассказ кстати» «Интересные мужчины» (1885) замечателен самым широким взглядом на боговедение и прощение Божие. Герой - юный и свежий корнет «Саша-розан», в котором «на мелководье» до рокового события никто не был способен прозреть «скрылтую теплоту, присущую глубоким водам» $(7,320)$, застрелился, чтобы только не выдать тайну своего безответного чувства к молодой полковнице. Событие происходило в пятницу на шестой неделе Великого поста, звонили к вечерне. Автор точно определяет художественное пространство и время:

...церкви были полуосвещены, и из них выходили сложившие свои грехи исповедники $(7,323)$.

Но как «светлый мартовский день сгас своим румяным закатом» (7, 323), так Саша предпочел добровольно уйти из жизни, не сознавшись в грехе своей любви к чужой жене.

Ранее, в повести «Очарованный странник» (1873), Лесков поднял проблему возможности моления за самоубийц: попик-запивашка в своем видении получил такие полномочия от самого святого Сергия Радонежского. В «Интересных мужчинах» люди самого разного звания, потрясенные судьбой "Саши-розана», также соединились в общем молитвенном порыве за благородного юношу:

...припадали с этим к Господу-то!.. Да ведь с слезами-с, с каким плачем-с!.. Как велик грех Саши-розана по богословской науке - в этом оплакивавшие его были не знатоки, но уж умоляли «принять его в блаженные селенья» так неотступно, что я, право, не знаю, как тут согласить этот душевный вопль с точными положениями оной науки $(7,356)$.
«Песнотворческий гений Дамаскина» все выше возводит сердца, «его поэтический вопль и жжет, и заживляет рану... $<.>$

\section{Прими усопшего, Господь,}

В Твои блаженные селенья.

...Пристойнее и трогательнее с этим обходиться, как придумали восточные христиане, кажется, невозможно» (7, 356-357). С точки зрения ревнителей узко понимаемой чистоты веры, умоляющие простить самоубийцу «еретичествуют», однако герои Лескова, как и сам автор, горячо веруют в беспредельное милосердие Божие:

$O н$ ли, Который Сам создал ухо, чтобы все слышать, $O н$ ли задремлет, $O н$ ли уснет, $O H$ ли не сделает, что просит голос стольких растроганных душ... $(7,357)$.

В этих искренних упованиях не только надежда - это невыразимое знание, осердеченное верой.

Необычайный прилив тепла, ощущение внутреннего счастья передаются и тогда, когда автор рисует не православную богослужебную церемонию во всем ее великолепии, а простую задушевную молитву ко Всевышнему (таковы моления праведника Константина Пизонского в «Соборянах», отца Кириака в «На краю света», героя святочного рассказа "Христос в гостях у мужика» и многих других). Показателен эпизод повести «Юдоль» (1892), в котором рассказчик вспоминает о своем детском впечатлении от пения религиозного гимна на евангельский текст «Приходящего ко Мне не изгоню вон» (Ин. 4:37) тетей Полли и англичанкой-квакершей Гильдегардой. В этом фррагменте Лескову удалось описать духовно возвышенное состояние, «для которого нет расторгающего значения времени и пространства» $(11,193)$, то есть евангельскую «полноту времен» и «полноту сердца», при которых происходит встреча человека с Богом, - то состояние, которое лаконично выражено в Послании апостола Павла:

И уже не я живу, но живет во мне Христос (Гал. 2:20).

О, какая это была минута! Я уткнулся лицом в спинку мягкого кресла и плакал впервые слезами неведомого мне до сей поры счастья, и это довело меня до такого возбуждения, что мне казалось, будто комната наполняется удивительно тихим 
светом, и свет этот плывет сюда прямо со звезд, пролетает в окно, у которого поют две пожилые женщины, и затем озаряет внутри меня мое сердце, а в то же время все мы - и голодные мужики, и вся земля - несемся куда-то навстречу мирам... $\mathrm{O}$, если бы за все скорби жизни земной еще раз получить такую минуту при уходе из тела! $(11,193)$

Здесь отчетливо различимо, как Священное Писание «вживляется» в лесковский художественный текст, доминируют христианско-философские универсалии: жизнь и смерть, идущие рядом, и спасение в том, чтобы люди стали «лучше, чище, меньше самолюбивы и больше сострадательны и добры» $(11,192)$. Благой $c в е m$, долетающий со звезд, - возвышающий символ в головокружительном космизме религиозного экстаза анализируемой сцены. Звезды бросают свой отблеск на "светлые личности» праведных героинь Лескова. Звездное небо дает им «"зрение”, при котором можно все простить и все в себе и в других успокоить» $(11,205)$. Полон сокровенного смысла ответ тети Полли на недоуменный вопрос: «...мы все очень грешны, зачем нам мечтать так высоко! <..> 192).

- Надо поднилаться (выделено мной. - A. Н.) (11,

Правы исследователи, заметившие, что в произведениях Лескова «сокрыт большой пласт невербальной информации... второй, тайный смысл повествования» ${ }^{21}$. Благодаря христианской семантике лесковские художественные образы сакрализуются, наполняются религиозной метазначительностью. Для многих религиозно значимых произведений Лескова характерна энигматичность, загадочность, особенное соотношение высказанного и невысказанного. Неизреченное экстатическое состояние богопознания «Того, Кто превосходит все познаваемое» ${ }^{22}$, - nуть очищения и приобшения - становится источником метафизической неисчерпаемости лесковского текста.

${ }^{21}$ Прокофбева Т. А. О способах формирования художественного целого в рассказе Н. С. Лескова «На краю света» // Вестник МГУ. Филология. Сер. 9. 1989. № 4. С. 50 .

${ }_{22}$ Св. Дионисий Ареопагит. Мистическое богословие // Мистическое богословие. Киев, 1991. С. 11. 